\title{
CORRESPONDENCE
}

\section{Creation versus Evolution}

SIR,--In your editorial entitled "Creation in California" (Nature, 239, 420; 1972) you ask for scientists to identify themselves who do not hold to the "doctrine of evolution" (your terminology), who are working in a field related to the evolutionary question. I am a research chemist presently involved in work on biological membrane structure and function, and formerly on polypeptide and protein conformations, and am ready to state my dissenting position.

I do not believe that the evidence in hand demonstrates that the origin and development of life on Earth occurred by an evolutionary pathway. My objection is not to evolution on a small scale, that is microevolution, meaning the variation and development within related plant or animal groupings; indeed, I would go so far as to say that in my opinion this type of evolution has been proven to occur. One is not warranted, however, to extrapolate from the evidence for microevolution to the contention that general evolution is therefore also true.

The simplest living cells are still very complicated on a molecular level; to suppose that there were even simpler cells in the past is pure speculation designed to fit a theory. In any case, it is generally agreed that the coming into existence of the first living cell must have been an extremely improbable event, but we know it happened because cells now exist.

Natural phenomena may be defined as events which have a finite probability of happening, on the basis of known or at least knowable natural laws. Events which are extremely rare or which have a vanishingly small probability of occurrence cannot readily be classified as natural phenomena. The origin and development of life fall into this category. It must be admitted that such events may be the result of a supernatural act, unless one wishes arbitrarily to dismiss the possibility that God exists and that $\mathrm{He}$ can and does operate the universe. It is my reasoned opinion that the empirical evidence in hand concerning the nature and origin of life is better explained in terms of supernatural, creative acts than it is by the general theory of evolution.

The editor of Nature is to be complimented for providing a forum for the open discussion in scientific circles of the creation versus evolution question.

$$
\text { Your faithfully, }
$$
GARRET VANDERKoOI

Institute for Enzyme Research, 1710 University Avenue, University of Wisconsin,

Madison, Wisconsin 53706

SIR,-Your challenge (Nature, 239, 420 ; 1972) to those who do not believe that evolution supplies all answers on the existence of the universe, Earth and life cannot go unanswered.

I do not see that the existence of the universe, the Earth, and living systems can be separated from one another: you seem to be considering only the Earth and species but ignoring the whole question of beginnings. Even such an impersonal idea as a "master clockwinder" who established matter, perhaps set up some master laws (including evolution?) and is, for all intents and purposes, now "dead" should deserve more than one sentence in a science textbook. A God who took a direct part in organization of the universe should deserve far more recognition. You state that the "doctrine of evolution... deserves to be called the truth." Jesus Christ said, "I am the Truth" (John, 14, 6). If evolution proves the non-existence of God, then Jesus was a liar and the dichotomy need not be reconciled. If evolution does not speak to that question, then the possibility that God could have taken an active role in organization of the universe, Earth, and life is a viable alternative.

A chemical kineticist will state that his proposed mechanism is consistent with the kinetic data but that kinetics cannot prove a mechanism, for there may be other mechanisms just as consistent with the data. Then one must look for additional evidence to support or disprove the mechanism. There are too many unanswered questions in evolution for me to be able to call it "truth", so we must look for additional evidence. Two arguments will be presented.

If the essence of thermodynamics may be stated as given by Giles, "There exists an additive function of state $S$, called the entropy, and a set of additive functions of state, called components of content, such that, for any states $a$ and $b, a \rightarrow b$ if, and only if, $S(a) \leqslant S(b)$, and $Q(a)=Q(b)$ for every component of content $Q$ " (quoted by W. Brostow, Science, 178, 123; 1972), then simple examination states that something or someone larger than the universe must have formed the original state $a$ from which entropy is changing to this day. I understand that information theory and the second law of thermodynamics have been redefined and expanded to allow for living systems to drive constantly toward greater organization in contrast to the rest of the universe (advance statement on Gatlin, L., Information Theory and the Living System, Columbia University Press, 1972). Without having read the ideas, this seems to give to living systems a new form of "vitalism" such that in only one aspect of life (evolution), different forms of the laws of thermodynamics apply. Is it not better to have a God that is beyond the limits of the universe because $\mathrm{He}$ made it? Are not evolutionary trees of protein and nucleic acid structures just as well explained by a common originator as by a common origin? If so, is not the alternative mechanism of relationship of the species worthy of presentation?

The second argument is lacking an exact figure. At the AAAS meeting in Philadelphia last December, it was stated that it should be possible to synthesize more efficient proteins because there are $10^{72}(?$, I did not record the number) electrons in the universe and $20^{100}$ possible combinations of aminoacids (not to mention modification of specific residues by methylation, acetylation, phosphorylation, and so on) in a protein containing 100 amino-acid residues (one of the smallest proteins) so that evolution had to stop with a combination that worked and not necessarily the best (comments in parentheses are mine, not the speaker's). If there 
are $10^{10}$ to $10^{12}$ different kinds of protein molecules (Lehninger, in Biochemistry, 5, Worth Publishers) the probability of getting that many functional proteins with the limited material available would appear to be infinitesimal or at least such that reasonable doubt may be expressed that probability is the only answer. Intervention by God to make functional protein and nucleic acid is not disproved by these statements.

It would appear that the cardinal question is, "Is there a God?" If not, how can we prove that scientifically? If we cannot prove the absence of a God, then we must consider the possibility that there is a God and $\mathrm{He}$ could certainly also have the power to be active in the universe (a far more positive apology for the existence of God and what $\mathrm{He}$ means to individuals can be given, but I see the issue in your editorial as whether anyone in your readership feels that there is reasonable doubt that evolution supplies all the answers to a scientific mind). In my opinion there is sufficient doubt such that the California Board of Education cannot be told that "evolution is ... the truth" and no other alternatives need be considered.

A far more consistent universe may be studied if we are not left to the vagaries of probability but rather can study the works of an unchangeable and sovereign God. Such a basic philosophy concerning the universe can make for a more meaningful science, limited only by man's ability to discover and rightly interpret the works of God.

$$
\begin{aligned}
& \text { Yours faithfully, } \\
& \text { Harold VAN KLEY }
\end{aligned}
$$

\section{School of Medicine,}

\section{Edward A. Doisy}

Department of Biochemistry, 1402 South Grand Boulevard, Saint Louis, Missouri 63104

SIR,-I am a taxonomic botanist and have been for the last ten years.

I was at one time a convinced believer in evolution, but that was before I studied the subject with a critical eye. I now reject the whole thing as an utter tissue of lies, and have come to accept the fundamentalist position of divine creation as being the only possible explanation of origins-that is, with purpose and destiny, as opposed to blind meaninglessness, which is what evolutionism presupposes.

Too late was my attention drawn to your generous offer (Nature, 239, 420; 1972), but I am not so concerned about obtaining free copies of your journal as I am about making known God's truth.

May the light of God's holy word shine in upon and illuminate the souls of those whose understanding has been darkened by the specious arguments of the Devil, and may the sons of men sing praises to their Creator and Redeemer instead of paying lip-service to Satan.

\section{Yours faithfully, Alan RadCLIFFE-SMith}

The Herbarium,

Royal Botanic Gardens,

Kew

SIR,-With reference to your editorial comment "Creation in California" (Nature, 239, 420; 1972), though not a convinced creationist, and certainly not a supporter of the more extreme forms of creationism, I do want to defend the more moderate creationist views, which I think are scientifically tenable and so deserve to be considered alongside evolution.

Theories of the origin of life can be classified under three headings: naturalistic evolution, theistic evolution, and creationism. It is difficult to think of any scientific test to distinguish between the two evolutionary views. Creationists make postulates about the past that can be checked by the evidence and which differ from evolutionary postulates. All creationists hold to a polyphyletic view of the origin of life - a view that an evolutionist has shown to be scientifically tenable ${ }^{1}$. They believe in the original creation of a multitude of "kinds" of organisms (the term is not synonymous with "species") which have since undergone some speciation. Thus they predict the existence of gaps in the fossil record between the remains of the older forms or organisms, as is the case $\mathrm{e}^{2}$. Some creationists believe that there was only one creative act, which occurred some tens of thousands of years ago. Others hold that there were a series of such acts spread over hundreds of millions of years. These postulates can be tested. The first is at variance with radioactive dating (which its adherents regard as erroneous), but the second is in accord with the datings and the fossil record. Thus the more moderate creationist views are just as compatible with the evidence as the evolutionary views.

The present antipathy towards all forms of creationism arises, at least in part, from the invasion of science by an extra-scientific assumption-namely the belief that the universe is a closed system which cannot be invaded by the supernatural. This view was not held by the founders of modern science, most of whom were devout Christians, and is not an axiom essential for the practice of science (the essential axiom is that the supernatural interventions are non-capricious), nor is it deducible from the success of science (as fallaciously argued by Hume). Scientific investigation can only show whether or not a particular event was genuinely supernatural, not whether supernatural events in general can or cannot occur. The influence of this philosophical prejudice in science is well illustrated by the readiness to accept the idea of creation as a "natural law", as in the original steady-state cosmology, whilst rejecting the idea of creation as an "act of God". If it is objected that "acts of God" 'have no place in science, the answer is that if one chooses to hypothesize about the origin of things one must become unscientific in that origins are once-for-all happenings that cannot be experimentally verified. At best theories of origins can be falsified by comparison with the circumstantial evidence available. Also, if a creatorgod exists, then his creative act will be met at some point, if not the origin of life, then the origin of matter/energy. All this shows the importance of clearly stating one's philosophical and religious position when postulating theories of origins, since this inevitably influences such theories.

One final comment. Why was your "challenge" limited to university scientists? Are industrial scientists an inferior breed? Maybe they are freer thinkers as a result of being less affected by the pressures for conformist thinking that exist in universities. As a point of information, the Creation Research Society, one of the lobbies in California, has a few hundred members, all with higher degrees in science.

Yours faithfully,

$$
\text { E. C. Lucas }
$$

\section{Dyson Perrins Laboratory,}

South Parks Road, Oxford $O X 13 Q Y$

${ }^{1}$ Kerkut, G. A., Intern. Ser. Monogr. Pure App. Biol,, 4 (Pergamon, London, 1960).

2 Simpson, G. G., The Meaning of Evolution, 209 (Bantam Book, New York, 1971).

SIR, - I agree with the basic points you raised in your editorial on "Creation in California" (Nature, 239, 420 ; 1972). Being a former resident of that allegedly super-sophisticated state, I have witnessed first hand the emasculation of scientific truths in education that you spoke of. To set the record straight, the non-fundamentalist educational authorities of that state are just as much to blame for the institution of these measures as the "special creation" advocates. Take, for instance, the present Superintendent of Public Instruction there, whom I personally heard bluster: "Any method of teaching reading is as good as any other." Presumably he extends this eclectic approach to interpretation of biological facts as well.

The arguments of the special creationists usually involve irrelevant 